\title{
PERAN KELUARGA DALAM MENGANTISIPASI PENGARUH BUDAYA ASING PADA SISWA SDN 1 PENDEM JANAPRIA TAHUN AKADEMIK 2013/2014
}

\author{
Hidayati $^{1}$, Rima Rahmaniah ${ }^{2}$ \\ ${ }^{1,2}$ Dosen Program Studi Pendidikan Bahasa Inggris FKIP, Universitas Muhammadiyah Mataram \\ Email : bundahidayati2104@gmail.com
}

\begin{abstract}
ABSTRAK
Pendidikan sebagai suatu tugas dan kewajiban pemerintah dalam mengembangkan aspirasi rakyat harus mencerdaskan dan menuju kearah tercapainya masyarakat yang mampu menyaring budaya asing. Oleh karena itu maka tujuan penelitian ini adalah adakah peran keluarga dalam mengantisipasi pengaruh budaya asing pada siswa SDN 1 Pendem, Janapria. Metode yang dipergunakan untuk mengumpulkan data adalah observasi, angket dan dokumentasi sehingga dirapkan dengan metode ini maka analisi yang diperbunakan adalah kuantitatif dengan analisis korelasi product moment. Adapun metode penelitiannya adalah metode penelitian kuantitatif. Berdasarkan hasil penelitian maka analisis korelasi product moment di atas diperoleh nilai (r) sebesar 0,621. pada taraf kepercayaan (signifikan) sebesar 5\% atau 0,05 dengan df/db N-2 (44-2) = 42 orang, maka diperoleh $(r)$ tabel sebesar 0,304 dari hasil tersebut bahwa nilai $r$ lebih besar dari ( $r$ ) tabel yaitu $(0,621>0,304)$. Maka dapat dikatakan bahwa hipotesis kerja $(\mathrm{Ha})$ diterima atau terdapat hubungan yang signifikan antara peran keluarga terhadap pengaruh budaya asing, sedangkan hipotesis nilai (Ho) yang berbunyi tidak ada hubungan yang signifikan antara peran keluarga terhadap pengaruh budaya asing di SDN 1 Pendem Kecamatan Janapria Kabupaten Lombok Tengah tahun akademik 2013/2014 adalah ditolak. Sehingga kesimpulan dari penelitian ini adalah terdapat peran keluarga dalam Mengantisipasi Pengaruh Budaya Asing pada Siswa SDN 1 Pendem, Janapria Tahun Akademik 2013/2014.
\end{abstract}

Kata Kunci : keluarga, budaya asing

\section{PENDAHULUAN}

Dalam UUD No. 20 tahun 2003 tentang sistem pendidikan nasional menyatakan : bahwa tujuan pendidikan nasional adalah untuk meningkatkan kualitas manusia yaitu manusia yang beriman dan bertaqwa terhadap Tuhan Yang Maha Esa, berbudi pekerti luhur, berkepribadian, mandiri, maju tangguh, kreatif, terampil, berdisiplin, cerdas, beretos kerja, profesional, bertanggungjawab dan produktif serta sehat jasmani dan rohani.

Berpijak dari tujuan pendidikan di atas, maka sangat perlu ditingkatkan untuk kesadaran siswa agar senantiasa wajib mengikuti pendidikan di lingkungan sekolahnya. Tujuannya "agar setiap siswa mampu membentengi mental pada diri masing-masing dan semakin meningkatkan iman dan ketakwaan terhadap Tuhan Yang Maha Esa melalui pendidikan yang diperoleh" (Naquib Al Atas, 2001 dalam Muhiddin, 2009:1).

Sejalan dengan itu maka pendidikan sebagai suatu tugas dan kewajiban pemerintah dalam mengembangkan aspirasi rakyat harus mencerdaskan dan menuju kearah tercapainya masyarakat yang mampu menyaring budaya asing. Dalam kegiatan kemasyarakatan antara" pendidikan yang diperoleh di sekolah mampu meningkatkan dan mengantisipasi budaya asing yang bersifat negatif yang dihadapinya seperti minuman keras, narkoba dan lain sebagainya" (Ahmad, 2002: 24). Oleh karena itu pendidikan yang diselenggarakan khususnya dalam lingkungan keluarga merupakan sarana dalam kebudayaan manusia yang diasumsikan dapat merealisasikan potensi-potensi yang terpendam.

Dalam Undang-Undang Nomor 23 tahun 2002 pasal 26 ayat 1 ditetapkan kewajiban dan tanggung jawab keluarga dan orang tua sebagai berikut: (1) Mengasuh, memelihara, mendidik dan melindungi anak, (2) Menumbuh kembangkan anak sesuai dengan kemampuan, bakat dan minatnya dan, (3) Mencegah terjadinya perkawinan pada usia anak-anak (Undang-Undang tentang perlindungan anak, 2007-13).

Keluarga memiliki kewajiban untuk membina dan mengembangkan kepribadian anak-anaknya melalui pendidikan yang tepat guna. Dalam kehidupan masyarakat dalam upaya kegiatan pendidikan kepada anak-anak 
yang sedang dalam taraf pertumbuhan dan perkembangan.

Keluarga memiliki kewajiban untuk membina dan mengembangkan kepribadian anak-anaknya melalui pendidikan yang tepat guna agar anak-anak kelak dapat mengemban hidupnya secara manusiawi keluarga sangat memerlukan kegiatan yang berhubungan dengan belajar anak, kegiatan yang dimaksud adalah : menyediakan fasilitas belajar, mengawasi kegiatan belajar anak di rumah, mengawasi penggunaan waktu belajar di rumah, mengenal kesulitankesulitan belajar anak, dan menolong anak mengatasi yang dihadapi dalam belajar (Kartini Kartono, 2001 dalam Muhiddin, 2009:4)

Hal ini didukung oleh pernyataan, yang menyatakan bahwa sekolah dapat seharusnya mengambil peranan yang penting dalam pembinaan moral anak didik dan hendaknya dapat diusahakan agar sekolah menjadi lapangan yang baik bagi pertumbuhan dan perkembangan mental dan moral anak didik, di samping tempat pemberian pengetahuan, pengembangan, bakat, dan kecerdasan, dalam menjalankan pendidikan dengan sungguh-sungguh ikut mempengaruhi moral siswa di dalam kehidupan masyarakat (Nata, 2002 : 192)

Berdasarkan uraian tersebut diatas jelas bahwa peran keluarga sangat membantu keberhasilan dan kelangsungan proses pembelajaran dan pendidikan seorang anak, baik untuk masa kini maupun dimasa yang akan datang. Dengan demikian, berdasarkan hal tersebut maka saya tertarik untuk membuat penelitian yang sama dan sekaligus mengambilnya sebagai judul dalam penelitian ini yaitu peran keluarga terhadap pengaruh budaya asing di SDN 1 Pendem, Janapria yang sekaligus sebagai desa lokasi Kuliah Kerja Nyata Universitas Muhammadiyah Mataram angkatan XXVI tahun akademik 2013/2014.

\section{TINJAUAN PUSTAKA}

\section{A. Pengertian Keluarga}

Keluarga merupakan pilar utama dalam pembentukan kepribadian anak, sehingga keluarga disebut lingkungan yang pertama dan yang utama dalam dunia pendidikan. Tidak ada orang yang meragukan bahwa lingkungan keluarga memiliki peran penting dalam membentuk kepribadian anak di masa depan. Kebiasaan-kebiasaan yang terpola atau perilaku yang ditunjukkan orang tua kepada anak-anak sedikit demi sedikit akan diadopsi oleh anak yang bersangkutan sebagai bagian dari kepribadiannya. Oleh karena itu, keluarga adalah lembaga pendidikan yang sangat dominan dalam perkembangan jiwa anak-anak sehingga dalam sebuah karya disebutkan sebagai berikut :

Rumah tangga sebagai sebuah benteng yang kokoh dan dasar utama dalam pembentukan sebuah masyarakat, sehingga dari sanalah mesti diletakkan dasar pertama pembentukan sebuah masyarakat. Anak-anak yang hidup di masa sekarang merupakan individu masyarakat yang yang berharga di masa datang. Dari rumah tanggalah mereka mengambil pelajaran, baik kehidupan individual maupun sosial. Apa yang diperoleh seseorang dalam rumah tangga, khususnya semasa kanak-kanak akan tetap melekat pada dirinya. Bahkan lebih dari tujuh puluh persen dasar-dasar kepribadian dan prilaku manusia berkait erat dengan masa kanakkanaknya. Sementara itu, berdasarkan hasil penelitian pada beberapa kasus, para pakar kriminal memperoleh kesimpulan bahwa sembilan puluh dua persen dari para pelaku kriminal adalah mereka yang semasa kanakkanaknya hidup dalam rumah tangga (keluarga) yang tak seimbang dan tidak harmonis (Ali Qaimi, 2002 : 2).

Bertitik tolak dari pendapat ahli di atas, maka sekali lagi dapat ditegaskan bahwa tingkat perhatian keluarga mempunyai pengaruh dan peranan yang besar dalam kelangsungan proses belajar mengajar (pendidikan) dengan catatan bahwa semuanya itu dipergunakan semaksimal mungkin untuk membantu mendorong, dan merangsang jalannya proses pembelajaran dan pendidikan anak-anaknya di sekolah. Oleh karena itu, keteladanan dalam bersikap dan berperilaku bagi orang tua akan menjadi cermin yang dianggap sarana yang efektif untuk membina dan mengembangkan kepribadian anak. Orang tua harus dapat memberikan contoh-contoh perilaku yang baik, sehingga setiap orang tua dapat menjaga citra dirinya sebagai orang tua yang patut untuk diteladani oleh anak-anak.

\section{B. Peranan Kedudukan Keluarga}

Peranan keluarga dalam dinamika perkembangan anak untuk menuju ke dalam alam kedewasaannya adalah pondasi awal yang menentukan baik buruknya lingkungan yang tersedia dalam keluarga akan menjadi dasar tentang perkembangan kepribadian anak untuk melangkah ke masa depan. Oleh 
karena itu, orang tua adalah figure yang pertama bagi anak-anak untuk mengadopsi dan menginternalisasikan nilai-nilai yang positif ataupun negatif dalam jiwa seorang anak. Perilaku orang tua yang ditunjukkan pada kesehariannya dalam lingkungan keluarga akan menjadi bagian yang tidak terpisahkan dengan kepribadian anak, baik untuk masa kini maupun masa-masa yang akan datang.

Secara universal, keluarga memiliki kewajiban untuk membina dan mengembangkan kepribadian anak-anaknya melalui pendidikan yang tepat guna agar anak-anak kelak dapat mengembangkan hidup secara manusiawi. Keluarga sebagai salah satu institusi sosial dalam kehidupan masyarakat memiliki posisi yang strategis dalam upaya kegiatan pendidikan kepada anak-anak yang sedang dalam taraf pertumbuhan dan perkembangan. Sebab karena dalam lingkungan keluarga merupakan ladang subur bagi tumbuhnya cinta (kasih sayang) sebagai modal utama dalam pendidikan itu sendiri, seperti dinyatakan dalam suatu karya bahwa "orang tua memiliki rasa kasih sayang yang memungkinkan ia menjaga anaknya dengan sebaik-baiknya". (M. Nashir Ali, 2002 : 74)

Oleh karena itu, orangtua memiliki beberapa kewajiban dalam aspek pendidikan bagi anak-anaknya sebagaimana yang digariskan oleh seorang pakar sebagai berikut.

a. Memberi keteladanan yang baik bagi anak-anaknya dalam berpegang teguh kepada nilai-nilai yang mulia

b. Menyediakan bagi anak-anaknya peluang-peluang dan suasana praktis

c. Memberi tanggung jawab yang sesuai kepada anak-anaknya supaya mereka merasa bebas memilih tingkah lakunya

d. Menjaga mereka dari teman-teman yang menyeleweng dan tempat-tempat kerusakan dan lain-lain (Langgulung, 2005 : 375).

Dalam meningkatkan pendidikan anak-anaknya, keluarga sangat memerlukan suatu cara dan kegiatan yang berhubungan dengan belajar anak, kegiatan yang dimaksud adalah (1) Menyediakan Fasilitas Belajar, (2) Mengawasi kegiatan belajar anak di rumah, (3) Mengawasi penggunaan waktu belajar di rumah, dan (4) Menolong anak mengatasi kesulitan yang dihadapi dalam belajar.

\section{Pengertian Kebudayaan}

hanya manusia yang menghasilkan kebudayaan. Dengan akal budi yang dimilikinya, manusia membentuk kebudayaan, istilah budaya berasal dari kata sanksekerta yaitu "BUDDAYAH atau BUDDHI yang berarti akal budi, kebudayaan berarti segala sesuatu yang dihasilkan oleh akal budi manusia.

Ada tiga bentuk kebudayaan sebagai berikut :

1. Kebudayaan yang berupa gagasan yaitu antara lain ilmu pengetahuan, adat istiadat dan peraturan

2. Kebudayaan yang berupa kebiasaan, antara lain cara mencari makan (mata pencarian), tata cara pergaulan, tata cara perkawinan, kesenian, dan bermacammacam upacara tradisi.

3. Kebudayaan yang berupa adalah semua benda yang diciptakan oleh manusia seperti alat-alat keperluan sehari-hari rumah, perhiasan, pusaka (senjata) kendaraan dan lain-lain.

Keanekaragaman budaya merupakan kekayaan bangsa Indonesia, kebudayaankebudayaan daerah merupakan modal utama untuk mengembangkan kebudayaan nasional. Kebudayaan nasional adalah puncak-puncak kebudayaan daerah yang ada di wilayah Indonesia. Kebudayaan daerah yang dapat menjadi kebudayaan nasional harus memenuhi syarat-syarat seperti:

a. Menunjukan ciri atau identitas bangsa

b. Berkualitas tinggi sehingga dapat diterima oleh seluruh Bangsa Indonesia

c. Pantas dan diangkat sebagai budaya nasional

Kebudayaan adalah hasil kegiatan dan penciptaan bathin (akal budi) manusia seperti kepercayaan, kesenian, dan adat istiadat atau keseluruhan pengetahuan manusia sebagai makhluk sosial yang digunakan untuk memahami lingkungan serta pengalamannya dan menjadi pedoman tingkah lakunya.

Adapun sistem budaya di Indonesia terdiri dari :

1. Sistem budaya etnik

2. Sistem budaya agama besar

3. Sistem budaya Nasional

4. Sistem Budaya Asing

\section{Kebudayaan Asing}

Perubahan budaya yang terkait dengan masalah nilai, perilaku dan karya/produk itu bergerak menurut waktu. "Perubahan budaya tersebut bisa saja 
disebabkan oleh kreatifitas dari masyarakat itu sendiri atau juga bisa dari intervensi luar yang dimasukkan ke dalam masyarakat itu (faktor eksternal) melalui berbagi bentuk rekayasa sosial" (Marimba Ahmad, 2002 : 95).

Pengaruh dari kebudayaan barat membawa implikasi positif dan negatif yang perlu ditelaah secara arif dalam menghadapi dan mensikapinya. Pengaruh negatif yang patut diwaspadai adalah : (1) Munculnya kehidupan malam dalam bentuk baru yang tadinya tidak ada sama sekali dibagian dunia sini, terutama dengan adanya tarian-tarian telanjang, (2) Timbulnya semacam perdagangan seks. Yang jelas kelihatan dari adanya tarian telanjang dan munculnya apa yang dinamakan hostess dan beauty contest yang sebenarnya tidak lebih dan tidak kurang adalah memperdagangkan keluwesan dan kecantikan tubuh wanita untuk keuntungankeuntungan material dan menjadikan mereka sebagai obyek seksual belaka. (Faisal Ismail, 2006: 115)

Sedangkan pengaruh positif yang barangkali paling penting pada dewasa ini adalah ilmu pengetahuan dan teknologi, yang pada mulanya dikembangkan dan berasal dari dunia barat. Secara faktual banyak negara yang telah membeli teknologi, mengadaptasi dengan mempergunakan teknologi barat adalah usaha modernisasi dan mempergunakan teknologi barat dalam usaha modernisasi yang dilakukan oleh berbagai bangsa dibeberapa negara belahan dunia. Karena hal ini mereka sadari, bahwa dengan cara membeli, mengadaptasi dan mempergunakan teknologi dan ilmu pengetahuan barat, maka cara-cara yang dilaksanakan oleh bangsa-bangsa tersebut akan mempercepat akselerasi modernisasi yang sedang dilakukannya.

Secara umum, masuknya teknologi asing yang belum sesuai dengan situasi dan kondisi budaya masyarakat yang sedang berkembang mengakibatkan terjadinya cultural, yaitu ketimpangan taraf kemajuan pada beberapa unsur kebudayaan dalam suatu masyarakat. Dari sudut waktu istilah tersebut dapat dikatakan sebagai "ketertinggalan kebudayaan yaitu terdapat selang waktu antara saat benda (teknologi) itu diperkenalkan pertama kali dan saat benda (teknologi) itu dapat diterima oleh masyarakat sekaligus dapat menyesuaikan diri terhadap penggunaan benda (teknologi) tersebut" (Soeleman Moenandar, 2004 : 31).
Suatu cultural terjadi apabila irama perubahan dari dua unsur (atau lebih) perubahan memiliki korelasi yang tidak sebanding sehingga unsur yang satu tertinggal oleh unsur yang lain. Cultural dapat terjadi karena terdapat perkembangan yang tidak seimbang antara opini-opini, ide-ide dan nilai-nilai baru yang masuk dengan nilai budaya tertentu yang seharusnya sudah dimiliki sebagai suatu masyarakat. Bila prasyarat ini tidak terpenuhi, orang akan mengalami kebingungan ataupun ketidaktahuan dan akan cenderung sikap indisipliner, sikap mental menerabas, sikap fanatik, berpandangan sempit, keterasingan dan ketergoncangan akan kebudayaan sendiri dan sebagainya.

\section{Pengaruh Budaya Asing}

Masalah budaya dalam masyarakat harus diperjuangkan, agar budaya bangsa berakar pada ajaran agama, bukan berakar pada reka-rekaan sendiri saja atau budaya ikut arus. Pendidikan bisa menjadikan orang berkualitas bila mereka beragama secara benar sesuai dengan tuntutan agama. Untuk menjadi orang yang benar maka harus memperoleh dorongan yang aktif dan berada dalam suasana budaya (pembudayaan) yang mendukung. Mereka akan menjadi "manusia yang berkualitas rendah dan lemah bila dalam proses hidupnya dalam suasana budaya yang berlawanan (asing) dengan nilai ajaran pendidikan" (Abrasyi Muhammad Athiyah, $2004: 26)$

Mengkaji secara lebih mendalam bentuk-bentuk pengaruh budaya asing sehingga dapat diketahui dampak fositif dan dampak negatifnya dilihat dari sudut pandang ideologi, politik, ekonomi, sosial, budaya, maupun pertahanan dan keamanan nasional, pengaruh-pengaruh dampak positif maupun negatif dari adanya sentuhan budaya asing terhadap masyarakat Indonesia pada umumnya. Terutama bagi pihak penentu kebijakan dalam rangka meningkatkan pola penerimaan nilai-nilai baru yang memperkaya kebudayaan nasional dan sekaligus bertumpu kepada budaya daerah tanpa mengensampingkan prinsip yang terkandung dalam sila-sila Pancasila dan Undang-undang Dasar 1945.

Kesadaran bangsa Indonesia yang berbhineka dalam memperkaya budaya daerah yang menjunjung tinggi dan memperkaya budaya nasional, memerlukan kemampuan yang tinggi pula untuk mengembangkan budaya daerah yang 
dimilikinya. Terutama terhadap kandungan nilai-nilai luhur yang beradab, yang mampu kebudayaan nasional membenarkan masuknya budaya asing yang memeliki nilai fositif sebagai akibat pergaulan dunia, namun prioritas dan dominasi harus tetap berada pada budaya yang berakar pada budaya daerah

\section{Peranan Pendidikan dalam Mengantisipasi Pengaruh Budaya Asing}

Pada masyarakat umum terlihat pada sebagian sikap mereka yang dengan mudah merampas hak orang lain (menjarah), main hakim sendiri, melanggar peraturan tanpa merasa bersalah, mudah terpancing emosinya dan lain sebagainya. Sedangkan yang menimpa pelajar terlihat dari banyaknya keluhan orang tua, ahli didik dan orang-orang yang berkecimpung dalam bidang agama dan sosial berkenaan dengan ulah sebagian pelajar yang sukar dikendalikan, nakal, keras kepala, sering membuat keonaran, tawuran, mabuk-mabukan, pesta obat-obat terlarang, bergaya hidup seperti hippies, bahkan sudah melakukan pembajakan, pemerkosaan, pembunuhan dan perilaku kriminal lainnya

Menghadapi fenomena tersebut, tuduhan seringkali diarahkan kepada dunia pendidikan sebagai penyebabnya. Dunia pendidikan benar-benar tercoreng wajahnya dan tampak tidak berdaya untuk mengatasi pengaruh budaya asing. $\mathrm{Hal}$ ini bisa dimengerti karena pendidikan berada barisan terdepan dalam menyiapkan SDM (Sumber Daya Manusia) yang berkualitas dan secara moral memang harus berbuat demikian. Itulah sebabnya belakangan ini banyak sekali seminar yang digelar kalangan pendidik yang bertekad mencari solusinya. Para pemikir pendidikan menyerukan "Agar kecerdasan akal diikuti dengan kecerdasan moral, pendidikan agama dan pendidikan moral harus siap menghadapi tantangan global, pendidikan harus memberikan kontribusi yang nyata dalam mewujudkan masyarakat yang semakin berbudaya" (Abudin Nata, 2002 : 210).

Akar-akar penyebab timbulnya pengaruh moral tersebut cukup banyak, yang terpenting diantaranya adalah sebagai berikut: (1) Pengaruh moral terjadi karena longgarnya pegangan terhadap agama yang menyebabkan hilangnya pengontrol diri dari dalam (self control). (2). Pembinaan moral yang dilakukan oleh orang tua, sekolah dan masyarakat sudah kurang efektif. Ketiga institusi pendidikan ini sudah terbawa oleh arus kehidupan yang lebih mengutamakan materi tanpa diimbangi dengan pembinaan moral spiritual (Nata, 2002 : 222).

Sejalan dengan sebab-sebab timbulnya pengaruh moral tersebut, maka cara untuk mengatasinya dapat ditempuh dengan langkah-langkah sebagai berikut :

1. Pendidikan moral akhlak dapat dilakukan dengan menetapkan pelaksanaan pendidikan agama baik di rumah, sekolah maupun masyarakat. Hal yang demikian diyakini, karena inti ajaran agama adalah akhlak yang mulia yang bertumpu pada keimanan kepada Tuhan.

2. Mengintegrasikan antara pendidikan dan pengajaran. Hampir semua ahli pendidikan sepakat, bahwa pengajaran hanya berisikan pengalihan pengetahuan, keterampilan dan pengalaman yang ditujukan untuk mencerdaskan akal dan memberikan keterampilan. Sedangkan pendidikan tertuju kepada upaya membantu kepribadian, sikap dan pola hidup yang berdasarkan nilai-nilai yang luhur.

3. Pendidikan akhlak harus didukung oleh kerjasama yang kompak dan usaha yang sungguh-sungguh dari orang tua (keluarga), sekolah dan masyarakat. Orang tua di rumah harus meningkatkan perhatiannya terhadap anak-anaknya dengan meluangkan waktu untuk memberikan bimbingan, keteladanan dan pembiasaan yang baik. Orang tua juga harus berupaya menciptakan rumah tangga yang harmonis

4. Pendidikan harus menggunakan seluruh kesempatan, berbagai sarana termasuk teknologi modern. Kesempatan bereaksi, pameran, kunjungan, berkemah dan sebagainya harus dilihat sebagai peluang untuk membina akhlak (Abudin Nata, 2002 : 224).

\section{METODOLOGI PENELITIAN}

Metode yaitu merupakan cara yang dilakukan dalam mencapai tujuan, dengan demikian metode adalah suatu cara untuk memperoleh apa yang diinginkan dalam suatu penelitian. Dalam penelitian ini metode yang digunakan adalah metode penelitian deskriptif.

Yang dimaksud dengan metode penelitian deskriptif adalah penelitian yang berusaha mendeskripsikan suatu gejala peristiwa, kejadian yang terjadi pada saat sekarang. Dengan kata lain "penelitian 
deskriptif memusatkan masalah atau perhatian pada masalah aktual sebagaimana adanya pada saat penelitian" (Suharsimi Arikunto, 2010:96).

\section{A. Teknik Penentuan Subjek Penelitian}

Populasi adalah "seluruh individu yang dapat dijadikan subyek penelitian (I B, Netra, 2001 : 10). Ahli lain mengatakan bahwa populasi adalah semua elemen atau individu yang dapat dijadikan subyek penelitian" (Suharsimi Arikunto, 2002 : 10). Yang menjadi populasi dalam penelitian adalah siswa kelas $\mathrm{V}$ dan VI SDN 1 Pendem yang mengikuti kursus bahasa Inggris yang merupakan program mahasiswa KKN UMM yang dilakukan di desa Pendem, Janapria.

Sampel adalah "sebagian atau wakil populasi yang diteliti" (Suharsimi Arikunto, 2002 : 115). Ada berbagai teknik sampling yang dapat diterapkan dalam suatu penelitian. Dalam hubungan itu, teknik sampling yang akan dipergunakan dalam penelitian ini adalah teknik proporsional stratified random sampling, yakni teknik yang digunakan bila populasi mempunyai anggota/unsur yang tidak homogen dan berstrata secara proporsional yaitu pengambilan sampel secara acak terhadap semua subjek di dalam populasi.

\section{B. Metode Pengumpulan Data}

Metode pengumpulan data yang dilakukan dalam penelitian ini adalah metode observasi, wawancara, angket dan dokumentasi yang dilakukan pada siswa yang mengikuti kursus bahasa Inggris di SDN 1 Pendem, Janapria.

C. Teknik Analisis Data

Teknik analisis data yang dipergunakan dalam penelitian ini adalah teknik analisis kuantitatif dengan rumus korelasi product moment, sebagai berikut :

$$
r_{X Y}=\frac{N \sum X Y-\sum X \sum Y}{\sqrt{\left\{N \sum X^{2}-\left(\sum X\right)^{2}\right\}\left\{N \sum Y^{2}-\left(\sum Y\right)^{2}\right\}}}
$$

Keterangan :

$r_{X Y}=$ Angka indeks (Koefisien Korelasi) kedua variabel

$\sum X=$ Jumlah skor kemampuan mengantisipasi budaya asing

$\sum Y=$ Jumlah skor prestasi belajar

$N \quad=$ Jumlah responden

\section{HASIL DAN PEMBAHASAN}

A. Deskripsi Data

Untuk menjelaskan data yang telah dikumpulkan sesuai dengan tujuan penelitian ini, maka dalam tabel di bawah ini ,data yang dimaksud akan dideskripsikan sesuai dengan data variable dalam penelitian ini yakni data tentang peran orang tua dalam mengantisipasi pengaruh budaya asing. Adapun prosedur untuk mendeskripsikan data dimaksud adalah sebagai berikut:

\section{Tabel 4.1 Data Hasil Angket}

\begin{tabular}{|c|c|c|c|c|c|}
\hline No & Nama & $L / P$ & KIs & $\begin{array}{c}\text { Peran } \\
\text { Keluar } \\
\text { ga }\end{array}$ & $\begin{array}{c}\text { Antisi } \\
\text { pasi } \\
\text { Buday } \\
\text { a } \\
\text { Asing }\end{array}$ \\
\hline 1 & 2 & 3 & 4 & 5 & 6 \\
\hline 1 & Bq. Y & $\mathrm{P}$ & V & 40 & 38 \\
\hline 2 & WA & L & V & 38 & 32 \\
\hline 3 & MR & $\mathrm{L}$ & $\mathrm{V}$ & 38 & 36 \\
\hline 4 & WB & $P$ & V & 36 & 34 \\
\hline 5 & SN & $\mathrm{P}$ & $\mathrm{V}$ & 38 & 36 \\
\hline 6 & $\mathrm{AE}$ & $L$ & $\mathrm{~V}$ & 40 & 38 \\
\hline 7 & MK & $\mathrm{P}$ & $\mathrm{V}$ & 38 & 32 \\
\hline 8 & $\mathrm{ME}$ & $\mathrm{L}$ & V & 38 & 36 \\
\hline 9 & $M$ & $\mathrm{P}$ & $\mathrm{V}$ & 36 & 34 \\
\hline 10 & YA & $\mathrm{P}$ & V & 38 & 36 \\
\hline 11 & $\mathrm{LH}$ & L & V & 40 & 38 \\
\hline 12 & TS & $\mathrm{L}$ & V & 38 & 32 \\
\hline 13 & NPY & $\mathrm{P}$ & V & 38 & 36 \\
\hline 14 & $\mathrm{HM}$ & $\mathrm{L}$ & V & 36 & 34 \\
\hline 15 & $\mathrm{DH}$ & $\mathrm{L}$ & $\mathrm{V}$ & 38 & 36 \\
\hline 16 & SA & $\mathrm{L}$ & $\mathrm{V}$ & 40 & 38 \\
\hline 17 & MK & $\mathrm{P}$ & V & 38 & 32 \\
\hline 18 & $\begin{array}{l}\text { Bq. } \\
\text { MD }\end{array}$ & $P$ & V & 38 & 36 \\
\hline 19 & AR & $\mathrm{P}$ & V & 36 & 34 \\
\hline 20 & Bq.MS & $\mathrm{P}$ & V & 38 & 36 \\
\hline 21 & $\mathrm{~B}$ & $\mathrm{~L}$ & V & 40 & 38 \\
\hline 22 & $\mathrm{DP}$ & $L$ & $\mathrm{~V}$ & 38 & 32 \\
\hline 23 & MD & $\mathrm{P}$ & $\mathrm{V}$ & 38 & 36 \\
\hline 24 & AP & $\mathrm{P}$ & V & 36 & 34 \\
\hline 25 & NA & $\mathrm{P}$ & V & 38 & 36 \\
\hline 26 & MR & $\mathrm{L}$ & V & 40 & 38 \\
\hline 27 & $\mathrm{FR}$ & $\mathrm{L}$ & $\mathrm{V}$ & 38 & 32 \\
\hline 28 & $\mathrm{H}$ & $\mathrm{P}$ & V & 38 & 36 \\
\hline 29 & 10 & $\mathrm{P}$ & $\mathrm{V}$ & 36 & 34 \\
\hline
\end{tabular}




\begin{tabular}{clllll}
\hline 30 & L.MF & $\mathrm{P}$ & $\mathrm{VI}$ & 38 & 36 \\
\hline 31 & $\mathrm{MS}$ & $\mathrm{P}$ & $\mathrm{VI}$ & 40 & 38 \\
\hline 32 & $\mathrm{PW}$ & $\mathrm{P}$ & $\mathrm{VI}$ & 38 & 32 \\
\hline 33 & $\mathrm{MI}$ & $\mathrm{L}$ & $\mathrm{VI}$ & 38 & 36 \\
\hline 34 & $\mathrm{DS}$ & $\mathrm{L}$ & $\mathrm{VI}$ & 36 & 34 \\
\hline 35 & $\mathrm{DW}$ & $\mathrm{P}$ & $\mathrm{VI}$ & 38 & 36 \\
\hline 36 & $\mathrm{H}$ & $\mathrm{L}$ & $\mathrm{VI}$ & 40 & 38 \\
\hline 37 & $\mathrm{MA}$ & $\mathrm{L}$ & $\mathrm{VI}$ & 38 & 32 \\
\hline 38 & $\mathrm{KA}$ & $\mathrm{L}$ & $\mathrm{VI}$ & 38 & 36 \\
\hline 39 & $\mathrm{MY}$ & $\mathrm{L}$ & $\mathrm{VI}$ & 36 & 34 \\
\hline 40 & $\mathrm{SP}$ & $\mathrm{L}$ & $\mathrm{VI}$ & 38 & 36 \\
\hline 41 & $\mathrm{NE}$ & $\mathrm{P}$ & $\mathrm{VI}$ & 40 & 38 \\
\hline 42 & $\mathrm{H}$ & $\mathrm{L}$ & $\mathrm{VI}$ & 38 & 32 \\
\hline $\begin{array}{l}43 \\
\mathrm{I}\end{array}$ & $\mathrm{L}$ & $\mathrm{VI}$ & 38 & 36 \\
\hline $\begin{array}{l}44 \\
\text { Ju }\end{array}$ & $\mathrm{A}$ & $\mathrm{VI}$ & 36 & 36 \\
\hline $\begin{array}{c}\text { mla } \\
\mathbf{h}\end{array}$ & $\mathbf{1 . 6 7 2}$ & $\mathbf{1 . 5}$ & & & \\
\hline
\end{tabular}

Sumber Data : Data hasil angket siswa SDN 1 Pendem, Janapria 2014.

\section{B. Analisis Data}

Bertitik tolak dari data di lapangan sebagaimana yang tertuang dalam tabel, selanjutnya dapat dianalisis sesuai dengan rumus yang telah ditentukan, namun sebelumnya mengingat metode analisis data yang dipergunakan adalah statistik, maka hipotesis kerja yang telah dirumuskan terdahulu.

Untuk mengetahui ada tidaknya peran orang tua dalam mengantisipasi pengaruh budaya asing digunakan analisis korelasi product moment $(r)$ yang sudah ditentukan. Maka prosedur analisis datanya dapat disimak melalui tabel kerja korelasi product moment sebagai berikut:

Tabel 4.2 Tabel Kerja Analisis Korelasi Product moment

\begin{tabular}{cccccc}
\hline No & $\mathbf{X}$ & $\mathbf{Y}$ & $\mathbf{X}^{2}$ & $\mathbf{Y}^{2}$ & $\mathbf{X y}$ \\
\hline $\mathbf{1}$ & $\mathbf{2}$ & $\mathbf{3}$ & $\mathbf{4}$ & $\mathbf{5}$ & $\mathbf{6}$ \\
\hline 1 & 40 & 38 & 1.600 & 1.444 & 1.520 \\
\hline 2 & 38 & 32 & 1.444 & 1.024 & 1.216 \\
\hline 3 & 38 & 36 & 1.444 & 1.296 & 1.368 \\
\hline 4 & 36 & 34 & 1.296 & 1.156 & 1.224 \\
\hline 5 & 38 & 36 & 1.444 & 1.296 & 1.368 \\
\hline
\end{tabular}

\begin{tabular}{llllll}
\hline 6 & 40 & 38 & 1.600 & 1.444 & 1.520 \\
\hline 7 & 38 & 32 & 1.444 & 1.024 & 1.216 \\
\hline 8 & 38 & 36 & 1.444 & 1.296 & 1.368 \\
\hline 9 & 36 & 34 & 1.296 & 1.156 & 1.224 \\
\hline 10 & 38 & 36 & 1.444 & 1.296 & 1.368 \\
\hline 11 & 40 & 38 & 1.600 & 1.444 & 1.520 \\
\hline 12 & 38 & 32 & 1.444 & 1.024 & 1.216 \\
\hline 13 & 38 & 36 & 1.444 & 1.296 & 1.368 \\
\hline 14 & 36 & 34 & 1.296 & 1.156 & 1.224 \\
\hline 15 & 38 & 36 & 1.444 & 1.296 & 1.368 \\
\hline 16 & 40 & 38 & 1.600 & 1.444 & 1.520 \\
\hline 17 & 38 & 32 & 1.444 & 1.024 & 1.216 \\
\hline 18 & 38 & 36 & 1.444 & 1.296 & 1.368 \\
\hline 19 & 36 & 34 & 1.296 & 1.156 & 1.224 \\
\hline 20 & 38 & 36 & 1.444 & 1.296 & 1.368 \\
\hline 21 & 40 & 38 & 1.600 & 1.444 & 1.520 \\
\hline 22 & 38 & 32 & 1.444 & 1.024 & 1.216 \\
\hline 23 & 38 & 36 & 1.444 & 1.296 & 1.368 \\
\hline 24 & 36 & 34 & 1.296 & 1.156 & 1.224 \\
\hline 25 & 38 & 36 & 1.444 & 1.296 & 1.368 \\
\hline 26 & 40 & 38 & 1.600 & 1.444 & 1.520 \\
\hline 27 & 38 & 32 & 1.444 & 1.024 & 1.216 \\
\hline 28 & 38 & 36 & 1.444 & 1.296 & 1.368 \\
\hline 29 & 36 & 34 & 1.296 & 1.156 & 1.224 \\
\hline 30 & 38 & 36 & 1.444 & 1.296 & 1.368 \\
\hline 31 & 40 & 38 & 1.600 & 1.444 & 1.520 \\
\hline 32 & 38 & 32 & 1.444 & 1.024 & 1.216 \\
\hline 33 & 38 & 36 & 1.444 & 1.296 & 1.368 \\
\hline 34 & 36 & 34 & 1.296 & 1.156 & 1.224 \\
\hline 35 & 38 & 36 & 1.444 & 1.296 & 1.368 \\
\hline 36 & 40 & 38 & 1.600 & 1.444 & 1.520 \\
\hline 37 & 38 & 32 & 1.444 & 1.024 & 1.216 \\
\hline 38 & 38 & 36 & 1.444 & 1.296 & 1.368 \\
\hline 39 & 36 & 34 & 1.296 & 1.156 & 1.224 \\
\hline 40 & 38 & 36 & 1.444 & 1.296 & 1.368 \\
\hline 41 & 40 & 38 & 1.600 & 1.444 & 1.520 \\
\hline 42 & 38 & 32 & 1.444 & 1.024 & 1.216 \\
\hline 44 & 36 & 34 & 1.296 & 1.156 & 1.224 \\
\hline & & & & & \\
\hline 13 & 36 & 1.444 & 1.296 & 1.368 \\
\hline 12 &
\end{tabular}




\begin{tabular}{cccccc}
\hline$\Sigma$ & 1.6 & 1.54 & 63.608 & 54.648 & 58.896 \\
\hline
\end{tabular}

Sumber Data : Data diolah. Siswa SDN 1 Pendem, Janapria 2014

$$
\begin{array}{ll}
\mathrm{X} & =1.672 \\
\mathrm{Y} & =1.548 \\
\mathrm{X}^{2} & =63.608 \\
\mathrm{Y}^{2} & =54.648 \\
\mathrm{XY} & =58.896 \\
\mathrm{~N} & =4
\end{array}
$$

Rumus yang telah ditetapkan adalah sebagai berikut:

$$
r_{X Y}=\frac{N \sum X Y-\sum X \sum Y}{\sqrt{\left\{N \sum X^{2}-\left(\sum X\right)^{2}\right\}\left\{N \sum Y^{2}-\left(\sum Y\right)^{2}\right\}}}
$$

Dengan demikian maka:

$$
\begin{aligned}
r & =\frac{44.58 .896-1.6721 .548}{\sqrt{\left.\left.\left\{(44.63 .608-1.672)^{2}\right\}(44.54 .648-1.548)^{2}\right\}\right\}}} \\
& =\frac{2.591424-2.588256}{\sqrt{\{2.798752-2.795584\{2.404512-2.396304}} \\
& =\frac{3.168}{\sqrt{3.168 .8 .208}} \\
& =\frac{3.168}{\sqrt{26.002 .944}} \\
& =\frac{3.168}{50.993 .081} \\
& =0,621
\end{aligned}
$$

\section{Pembahasan}

Berdasarkan hasil analisis korelasi product moment di atas diperoleh nilai $(r)$ sebesar 0,621. pada taraf kepercayaan (signifikan) sebesar $5 \%$ atau 0,05 dengan $\mathrm{df} / \mathrm{db} \mathrm{N}-2(44-2)=42$ orang, maka diperoleh (r) tabel sebesar 0,304 dari hasil tersebut bahwa nilai $r$ lebih besar dari $(r)$ tabel yaitu $(0,621>0,304)$. Maka dapat dikatakan bahwa hipotesis kerja $(\mathrm{Ha})$ diterima atau terdapat hubungan yang signifikan antara peran keluarga terhadap pengaruh budaya asing, sedangkan hipotesis nilai $(\mathrm{Ho})$ yang berbunyi tidak ada hubungan yang signifikan antara peran keluarga terhadap pengaruh budaya asing di SDN 1 Pendem Kecamatan Janapria Kabupaten Lombok Tengah tahun akademik 2013/2014 adalah ditolak.

Dalam mengantisipasi budaya asing, maka peran keluarga sangat diperlukan khususnya pada siswa di SDN 1 Pendem desa pendem Kecamatan Janapria Kabupaten Lombok Tengah karena merupakan desa yang menjadi jalur penghubung untuk beberapa tempat wisata yang ada di wilayah Lombok tengah dan Lombok Timur. Peran keluarga juga diharapkan dapat menyaring budaya asing melalui pendidikan agama agar anak-anak dapat melaksanakannya dalam nilai-nilai keseharian kehidupannya. Pendidikan agama juga selain sebagai pembelajaran dalam beribadah juga diharapkan dapat membangun moral siswa lebih baik kedepannya.

\section{KESIMPULAN DAN SARAN}

A. Kesimpulan

Berdasarkan analisis data, maka dapat ditarik beberapa kesimpulan bahwa terdapat pengaruh yang signifikan dari peran keluarga dalam mengantisipasi budaya asing yang dapat dilihat dari data sebagai berikut:

1. Hasil analisis korelasi product moment di atas diperoleh nilai $(r)$ sebesar 0,621, pada taraf kepercayaan (signifikan) sebesar $5 \%$ atau 0,05 dengan $\mathrm{df} / \mathrm{db} \mathrm{N}-2$ $(44-2)=42$ orang, maka diperoleh $(r)$ tabel sebesar 0,304 dari hasil tersebut bahwa nilai $r$ lebih besar dari $(r)$ tabel yaitu $(0,621>0,304)$. Maka dapat dikatakan bahwa hipotesis kerja $(\mathrm{Ha})$ diterima atau terdapat hubungan yang signifikan antara peran keluarga terhadap pengaruh budaya asing, sedangkan hipotesis nilai (Ho) yang berbunyi tidak ada hubungan yang signifikan antara peran keluarga terhadap pengaruh budaya asing di SDN 1 Pendem Desa Pendem Kecamatan Janapria Kabupaten lombok Tengah tahun akademik 2013/2014 ditolak.

2. Pendidikan adalah merupakan suatu proses pembuatan atau proses perubahan tingka laku yang dilakukan manusia terhadap manusia lainnya yang sesuai dengan tujuan pendidikan nasional yaitu untuk mencerdaskan kehidupan bangsa dan merngembangkan manusia Indonesia seutuhnya. Adapun pendidikan di sekolah yang merupakan institusi formal terdiri atas pendidikan dasar, pendidikan menengah, dan pendidikan tingkat tinggi.

3. Di dalam kebudayaan terdapat pengetahuan keyakinan seni dan moral, adat istiadat dan sebagainya 
menghasilkan sikap terpelihara sehingga kebudayaan bukanlah sekedar kesenian, dan kebudayaan pada hakekatnya adalah pola umum kegiatan manusia dalam berhubungan dengan sesamanya yang dilakukan oleh kelompok dalam masyarakat.

4. Keluarga memiliki kewajiban untuk membina dan mengembangkan kepribadian anak-anaknya melalui pendidikan yang tepat guna termasuk pendidikan agama di dalamnya agar anak-anak dapat mengembangkan hidupnya secara manusiawi yang tercermin dalam kesehariannya.

5. Kebudayaan nasional membenarkan masuknya budaya asing yang memiliki nilai positif sebagai akibat pergaulan dunia, namun prioritas dan dominasi harus tetap berada pada budaya yang berakar pada budaya daerah.

\section{B. Saran -Saran}

Berdasarkan hasil yang diperoleh dari penelitian ini maka penulis akan menyampaikan saran sebagai berikut:

1. Diharapkan kepada guru-guru SDN 1 Pendem, Janapria untuk memilih materi dalam memberikan pendidikan bahasa Inggris kepada siswa untuk membekali siswa tersebut untuk mengantisipasi budaya asing.

2. Diharapkan kepada siswa agar memperhatikan materi pembelajaran yang diberikan oleh guru sehingga terserap nilai-nilai aqidah dalam menerapkannya dalam kehidupan diluar sekolah.

3. Kualitas lingkungan keluarga seyogyanya harus secara berkesinambungan ditingkatkan melalui berbagai program pemberdayaan masyarakat agar kualitas generasi muda semakin baik kedepannya.

4. Kesadaran masyarakat untuk meningkatkan pengetahuan dalam rangka aplikasi pendidikan dalam keluarga semakin perlu digalakkan.

\section{DAFTAR PUSTAKA}

Adnan Normies, SAE, dkk, 2002. Kamus Bahasa Indonesia, Surabaya: PT. Karya Ilmu.

Amudi Pasaribu, 2005, Pengantar Metode Statistik, LP3ES Jakarta
Abudin Nata. 2000. Manajemen Pendidikan "Mengantisipasi Kelemahan Pendidikan di Indonesia". Jakarta:Raja Grafindo Persada.

Abu Ahmadi dan Faisal Ismail. 2006. Pengantar Psikologi Perkembangan. Surabaya:Usaha Nasional.

Djamarah, Bahri, Syaiful. 2004. Prestasi Belajar dan Kompetensi Guru. Surabaya:Pen. Usaha Nasional.

Djumuhur, 2000. Bimbingan dan Penyuluhan Di Sekolah. Yogyakarta:Andi Ofset.

Eddy Soewardi. 1987. Belajar yang Efektif dan Efisien. Bandung:Bina Karya.

Hasan Langgulung, 2005. Manusia dan Pendidikan. Jakarta:Al Husna Aksara

Ida Bagus Netra. 2001. Statistik Inferensial. Surabaya:Usaha Nasional.

Karti Soeharto, 2003. Teknologi Pembelajaran. Surabaya: Penerbit SIC.

M. Ngalim Purwanto. 1992. Psikologi Pendidikan. Bandung:Bina Aksara.

Marimba Ahmad. 2002. Pengantar Filsafat Pendidikan Islam. Bandung:Al Ma'arif.

Muhammad Al Naquib AL Atas. 2001. Islam dan Sekularisme Edisi Revisi IV. Bandung:Pustaka.

Muhibbin Syah. 2002. Dasar-Dasar Kependidikan. Bandung:Tarsito.

Nazir Muhammad, 2003. Metode Penelitian. Jakarta:Gahlia Indonesia

Narmies, dkk.2001. Masyarakat dan Komunikasi. Jakarta:Aneka Ilmu.

Nana Sudjana. 2001. Dasar-Dasar Kependidikan. Bandung:Bina Karya.

Pasaribu I L. dan B Simanjuntak 2003. Penelitian Pendidikan. Bandung:Sinar Baru Alga Sindo.

Soeleman Moenandar. 2004. IImu Budaya Dasar, Suatu Pengantar. Bandung:Eresco.

Suharsimi Arikunto. 2010. Metode Penelitian Suatu Pendekatan Praktis. Bandung: Transito. 